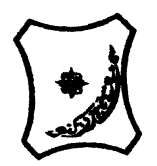

Bayero Journal of Pure and Applied Sciences, 14(1): 111 - 119

Received: January, 2021

Accepted: February, 2021

ISSN $2006-6996$

\title{
PHARMACOGNOSTIC, ANTIOXIDANT AND ACUTE TOXICITY STUDIES OF Vitellaria paradoxa STEM BARK AND ROOT EXTRACTS
}

\author{
Nuhu, $Y^{1}$., Haruna, $H^{1}$. , Namadina, $M . M^{1}$. , Haruna, $S^{2}$. , Abdulrazak, $M . H^{3} .$, \\ Yakasai, B.D ${ }^{4}$., Adamu, M.M ${ }^{5}$., Maitama, F.Y ${ }^{4}$, Karaye, S.I ${ }^{6}$. and Muttaka, A. ${ }^{7}$ \\ ${ }^{1}$ Department of Plant Biology, Bayero University, Kano, Nigeria. \\ ${ }^{2}$ Department of Forestry, Audu Bako Collage of Agriculture, Dambatta \\ ${ }^{3}$ Department of Biological Science, Sule Lamido University, Kafin Hausa, Jigawa State. \\ ${ }^{4}$ Department of Biological Sciences, Bayero University, Kano, Nigeria. \\ ${ }^{5}$ Department of Integrated Science, Saadatu Rimi Collage of Education, Kumbotso, Kano \\ ${ }^{6}$ Department of Forestry, Audu Bako Collage of Agriculture, Danbatta \\ ${ }^{7}$ Department of Biochemistry, Federal University Gusau \\ Corresponding Author: Hajiyaiyalle@gmail.commnmuhammad.bot@buk.edu.ng07030320052, \\ 07035939668
}

\begin{abstract}
Most of biochemical reactions in the body generates Reactive Oxygen Species (ROS) which are involved in the pathogenesis of oxidative stress-related disorders like diabetes, nephrotoxicity, cancer, cardiovascular disorders, inflammation and neurological disorders. Antioxidants are used to protect the cells or tissues against potential attack by ROS. Most medicinal plants possess a rich source of antioxidants such as flavonoids, phenols, tannins, alkaloids among others. These phytochemicals are currently pursued as an alternative and complimentary drug. The study was carried out to determine Pharmacognostic, antioxidant and acute toxicity of Vitellaria paradoxa root and stem bark. The Vitellaria paradoxa was extracted with water and methanol, screened for their phytochemical properties and antioxidant effects. Chemo-microscopical studies revealed the presence of cellulose cell wall, lignin, calcium oxalate crystals, tannins, starch and mucilage while calcium carbonate was absent in the stem bark but present in the root. The average moisture contents were $7.30 \%$ and $6.80 \%$ in stem bark and root respectively. The water and ethanol/alcohol extractives were $24.0 \%$ and $20.0 \%$ for stem while $25.50 \%$ and $19.0 \%$ for the root respectively. Alkaloid, flavonoids, saponins, tannins, steroids, triterpenes, carbohydrate and phenols were detected in both aqueous and methanol extracts while anthraquinones was absent in all the extracts. The DPPH radical scavenging ability of the extract showed the following trend Ascorbic acid > Stem bark extract $>$ Root extract. Toxicity of the samples was expressed as $L D_{50}$, it was found above $5000 \mathrm{mg} / \mathrm{kg}$ and did not cause mortality in all the tested rats.These results suggested that Vitellaria paradoxa root and stem bark have moderate antioxidant potentials. Further study is necessary for isolation and characterization of active antioxidant agents which can be used to treat various oxidative stress related diseases. Keywords: Antioxidant, Acute toxicity, DPPH, Phytochemical, Pharmacognostic, Vitellaria paradoxa,
\end{abstract}

\section{INTRODUCTION}

Free radicals are implicated in various diseases which include cancers, fever, diabetes, inflammation, neurodegenerative diseases, rheumatoid arthritis etc (Atinga, 2018). Reactive Oxygen Species (ROS) can damage the integrity of various biomolecules including lipids, proteins and DNA leading to increased oxidative stress in various human diseases such as diabetes mellitus, neurodegenerative diseases, rheumatoid arthritis, cataracts, cardiovascular diseases, respiratory diseases as well as in aging process. Vitellaria paradoxahas numerous folkloric uses, antioxidant being one but compound(s) responsible for this activity has been isolated and elucidated. Oxidative stress has been implicated in pathogenesis and progression of several lifestyle diseases like atherosclerosis, diabetes mellitus, hypertension, ischemic complications, malignancies, cardiovascular diseases, eye disorders, lung, pancreatic and kidney disorders, cancer as well as, ageing and diseases associated with reproductive system ( Rahman et al., 2012). 
BAJOPAS Volume 14 Number 1, June, 2021

Stress-related disorders have become epidemic in developing and under-developed countries. Conventional therapeutic strategies mostly attempt to relieve the clinical manifestations of these disorders and their complications. However, studies have shown they tend to increase toxicity leading to damage of sensitive organs like liver and brain, they are also suspected to be mutagenic (Krishnasamy, 2013). Against this backdrop, the popularity of complementary drugs for oxidative stress-related disorders has increased and plant based antioxidants therapies are now widely practiced in most of the developing countries (Mohan et al., 2013).

Vitellaria paradoxa belongs to the family sapotaceae it is commonly known as shea tree, shi tree, Vitellaria or Karite. The local names in Hausa are dan ka'raye, k'awara, ka'danya, mai ka'dai or mai ka' danya, while in Yoruba it is called aku malapa, emi-emi and in Igbo it is called okwuma (Hall et al., 1996). It is an indigenous plant to West Africa occurring in Mali, Cameroon, Cote d'ivoire, Ghana, Guinea Togo, Nigeria, Sudan, Senegal and Ethopia (Okollu et al., 2004), Burkina Faso and Uganda (Lovett and Haq 2000). Vitellaria paradoxa gum obtained from the latex of Vitellaria when dried can be used as a chewing gum base, but it does not have a very pleasant taste, washing improves the taste, but lowered or reduced the chewing quality of the gum (Hall et al., 1996). This work is aimed at evaluating the phytochemical and physiochemical properties of the gum of Vitellaria paradoxa so as to determine its suitability as a pharmaceutical excipient.

Despite the fact that the root and stem bark of Vitellaria paradoxa have several medicinal properties, no standardization parameter has been assessed. Due to lack of standard parameters, proper identification and ascertaining quality and purity of the root and stem bark of Vitellaria paradoxa in the events of adulteration has been thwarted. Since antioxidants hold a key in preventing oxidative stress-related disorders, many plant extracts and their secondary metabolites are being explored for their antioxidants effects (Gomathi et al., 2013). The use of plant based antioxidants, plays an important role in preventing activation of the oxidation induced signaling pathways in our bodies (Joseph et al., 2002). Therefore, the identification of the antioxidants activities of stem bark and root extracts of Vitellaria paradoxaare important step in increasing our understanding about their usage in treatment of various stress-related disorders.
MATERIALS AND METHODS

Collection and Identification of Plant Materials

The fresh Vitellaria paradoxastem bark and root was collected from local farms around Babura, Jigawa State, Nigeria. Samples from the plant were taken to the Herbarium unit of the Department of Plant Biology, Bayero University, Kano, Nigeria for authentication. The voucher specimen was deposited at the Herbarium with a reference code BUKHAN649.

The collected stem bark and root of Vitellaria paradoxa ere washed and dried at room temperature in the laboratory for one week. Samples were ground to powder using a mortar and pestle. The powdered plant samples were kept in polythene bags until extraction.

Chemo-microscopic Studies on the Stem of Vitellaria paradoxa

Powdered sample (stem bark and root) of Vitellaria paradoxa was used for this study to detect the presence of cell wall materials and cell inclusions. Finely ground sample of plant was cleared in a test tube containing $70 \%$ chloral hydrate solution. It was then be boiled on a water bath for about thirty minutes to remove obscuring materials. The cleared sample was mounted with dilute glycerol onto a microscope slide. Using various detecting reagents the presence of cell wall materials and cell inclusions was detected in accordance to WHO (2011) guidelines.

\section{Determination of Cell wall Materials \\ Test for Cellulose}

A drop or two of iodinated zinc chloride was added to the powdered sample and allowed to stand for a few minutes and observed under a microscope. It stained cellulose cell wall blue to blue- violet.

\section{Test for Lignin}

The powdered plant material was moistened on a slide with a small volume of phloroglucinol and allowed to stand for about two minutes or until almost dry. A drop of hydrochloric acid was added and view under a microscope. Pink stained or cherry red was observed, for the presence of lignin (WHO, 2011).

Test for Suberized or Cuticular cell walls

A drop or two of Sudan red was added to the cleared powdered sample and allowed to stand for few minutes and observed under a microscope. Orange red or red colour was observed presence of suberin or cutin on the cell.

\section{Test for Gum and Mucilage}

To a small portion of the cleared powdered sample of the plant, a drop of ruthenium red was added. Appearance of pink coloration was considered positive for gums and mucilage. 
BAJOPAS Volume 14 Number 1, June, 2021 Determination of Cell Inclusions/ Cell Contents

Test for Starch grains

To a small portion of the cleared powdered sample of the plant, N/50 iodine was added. Appearance of blue-black or reddish-blue coloration on some grains would be considered positive for starch.

\section{Test for Calcium oxalates and Calcium} Carbonates

To a small portion of the cleared powdered sample of the plant, $\mathrm{HCl}$ was added, dissolution of crystals in the powdered drug without effervescence was considered positive for calcium oxalate while slow dissolution with effervescence was considered positive for calcium carbonate.

\section{Inulin}

A drop of 1-naphthol and that of sulphuric acid was added to the powdered sample and viewed under the microscope. Spherical aggregations of crystals of inulin turned brownish red and dissolve.

\section{Test for Tannins}

To a small portion of the cleared powdered sample of the plant, $5 \%$ ferric chloride solution was added. Appearance of greenish black colour was considered as positive for tannins.

\section{Extraction of Plant Materials}

Powdered stem bark and root $(50 \mathrm{~g})$ of Vitellaria paradoxa were separately extracted with distilled water $(500 \mathrm{ml})$ followed by methanol $(500 \mathrm{ml})$ for 72 hours each using cold maceration. The extract obtained were concentrated using water bath, allowed to evaporate and stored in desiccator for further use.

\section{Determination of Physicochemical Parameters of the Powdered Stem bark and Root}

Some physicochemical parameters of the powdered sample of the plant such as moisture content, total ash, acid-insoluble ash, watersoluble ash, alcohol and water extractive values were determined (WHO, 2011).

\section{Moisture Content}

$3 \mathrm{~g}$ each of the powdered sample was accurately weighed and placed in some clean, dried evaporating dishes of known weights. They were placed in an oven and heated at a temperature of $105^{\circ} \mathrm{C}$ for 1 hour, then cooled in a desiccator and re-weighed. Heating and weighing were repeated until a constant weight was obtained. The weight loss on drying was computed following the formula below:

$$
\begin{aligned}
& \text { Percentage Moisture content } \\
& =\frac{\text { Initial Weight of Powder-Final Weight of Powder }}{\text { Initial Weight of Powder }} \times 100
\end{aligned}
$$

\section{Total Ash Value}

$2 \mathrm{~g}$ of powdered plant materials was accurately weighed and placed separately in a crucible of known weight. It was heated gently and the heat gradually increased until it is white indicating the absence of carbon. It was allowed to cool in a desiccator and weighed; this was repeated until a constant weight was obtained. The total ash value was determined as a percentage with the formula below

Percentage Ash Value $=\frac{\text { Weight of Residual Ash }}{\text { Original Weight of Powder }} \times 100$

\section{Acid-insoluble ash}

This was determined for the powdered plant material. $25 \mathrm{ml}$ of dilute hydrochloric acid was added to the crucible containing ash. It was covered with a watch glass and gently boiled for 5 mins. The watch glass was rinsed with $5 \mathrm{ml}$ of hot water and the liquid added to the crucible. The insoluble matter was collected on an ash less filter-paper and washed with hot water until the filtrate is neutral. The filter-paper containing the insoluble matter was transferred to the original crucible, dried in an oven and ignited to a constant weight. The residue was allowed to cool in a suitable desiccator for 30 minutes and then weighed without delay (Evans, 2009).

The acid-insoluble ash will then be calculated as a percentage for each of the two plants with the formula

Percentage Acid insoluble Ash $=\frac{\text { Weight of Residual Ash }}{\text { Original Weight of Powder }}$ X 100\%

\section{Water soluble ash}

To the crucible containing the total ash, $25 \mathrm{ml}$ of water was added and boiled for 5 minutes. The insoluble matter was collected in a sintered glass crucible. It was then be washed with hot water and ignited in a crucible for 15 minutes at $105^{\circ} \mathrm{C}$. The weight of the residue was subtracted from the weight of the total ash. The content of water soluble ash per air dried powdered sample was calculated and recorded (WHO, 2011).

Percentage Water Soluble Ash = $\frac{\text { Weight of Total Ash-Weight of Residual Ash }}{\text { Original Weight of Powder }}$ X 100\%

\section{Alcohol-Soluble Extractive Value}

$4 \mathrm{~g}$ of each of the plant material was separately weighed in a conical flask. $100 \mathrm{ml}$ of ethanol was added and macerated for 24 hours, during which the mixture was frequently shaken within the first 6hours using a mechanical shaker. It was filtered and $25 \mathrm{ml}$ of the filtrate transferred into an evaporating dish of known weight and evaporated to dryness on a water bath. It was dried to a constant weight, the percentage of alcohol-soluble extractive value was then determined for the plant as 
BAJOPAS Volume 14 Number 1, June, 2021

Percentage Ethanol Extractive Value
$=\frac{\text { Weight of Extract in } 25 \mathrm{ml} \times 4}{\text { Original Weight of Powder }} \times 100 \%$
Water-Soluble Extractive Value

Water-Soluble Extractive Value

Same procedure as in alcohol-soluble extractive value was repeated here for the sample, but solvent for extraction here was water.

Percentage Water Extractive Value $=\frac{\text { Weight of Extract in } 25 \mathrm{ml} \mathrm{X} 4}{\text { Original Weight of Powder }} \times 100 \%$

Preparation of Plant extracts

Fifty $(50 \mathrm{~g})$ of the powdered stem bark and root were soaked in to $500 \mathrm{~m}$ leach of methanol and distilled water. The mixture were allowed to stand for 3days at room temperature $\left(28 \pm 2^{\circ} \mathrm{C}\right)$ with hourly agitations. Each extract was sieved through a muslin cloth, filtered through a Whatman (No.1) filter paper, poured unto a clean evaporating dish and placed on a water bath at $50^{\circ} \mathrm{C}$ until all the solvent evaporated.

Qualitative Phytochemical screening of Vitellaria paradoxa Stem bark and Root extracts

The plant extracts were subjected to phytochemical screening in order to identify the phytochemical constituents of the plant using the method described below.

\section{Tests for carbohydrates}

Molish's (General) Test for Carbohydrates

To $1 \mathrm{ml}$ of the extract, $1 \mathrm{ml}$ of Molish's reagent was added in a test tube, followed by $1 \mathrm{ml}$ of concentrated sulphuric acid down the test tube to form a lower layer. A reddish colour at the interfacial ring indicates the presence of carbohydrate (Evans, 2009).

\section{Tests for Saponins}

\section{Frothing test}

About $10 \mathrm{ml}$ of distilled water was added to a portion of the extract and was shaken vigorously for 30 seconds. The tube was allowed to stand in a vertical position and was observed for $30 \mathrm{mins}$. A honeycomb froth that persists for $10-15$ mins indicates presence of saponins (Evans, 2009).

\section{Test for Flavonoids}

\section{Shinoda Test}

A portion of the extract was dissolved into $1-2 \mathrm{ml}$ of $50 \%$ methanol in the presence of heated metallic magnesium chips and few drops of concentrated hydrochloric acid were added. Appearance of red color indicates presence of flavonoids (Evan, 2009).

\section{Test for Alkaloids}

\section{Wagner's Test}

Few drops of Wagner's reagents were added to a portion of the extract, whitish precipitate indicates the presence of alkaloids (Evans, 2009).
Test for Steroids and Triterpenes Liebermann-Burchard's test:

Equal volume of acetic acid anhydride were added to the portion of the extract and mixed gently. Concentrated sulphuric acid $(1 \mathrm{ml})$ was added down the side of the test tube to form a lower layer. A colour change observed immediately and later indicates the presence of steroid and triterpenes. Red, pink or purple colour indicates the presence of triterpenes while blue or blue green indicates steroids (Evans, 2009).

\section{Test for Cardiac Glycosides}

\section{Kella-killiani's test:}

A portion of the extract was dissolved in $1 \mathrm{ml}$ of glacial acetic acid containing traces of ferric chloride solution. This was then transferred into a dry test tube and $1 \mathrm{ml}$ of concentrated sulphuric acid was added down the side of the test tube to form a lower layer at the bottom. Interphase for purple-brown ring was carefully observed, this indicates the presence of deoxy sugars and pale green colour in the upper acetic acid layer indicates the presence of cardiac glycosides (Evans, 2009).

\section{Test for Tannins}

Ferric chloride test:

Exactly 3-5 drops of ferric chloride solution was added to the portion of the extract. A greenish black precipitate indicates presence of condensed tannins while hydrolysable tannins give a blue or brownish blue precipitate (Evans, 2009).

\section{Test for Anthraquinones \\ Borntrager's test:}

Exactly $5 \mathrm{ml}$ of chloroform was added to the portion of the extract in a dry test tube and shaken for at least 5 mins. This was filtered and the filtrate shaken with equal volume of $10 \%$ ammonium solution, bright pink colour in the aqueous upper layer indicates the presence of free anthraquinones (Evans, 2009).

\section{Antioxidant activity Procedure}

The antioxidant activity of the plant extractswas measured in terms of radical scavenging ability, using a stable radical 2,2-diphenyl-1picrylhydrazyl (DPPH) according to the modified method adopted from (Sani and Dailami, 2015). $200 \mu \mathrm{l}$ of $100 \mu \mathrm{M}$ methanol solution of DPPH were added to $100 \mu \mathrm{L}$ of various concentrations of the sample fractions in methanol $(1000,500,250$, $125,62.5,31.25,15.63$ and $7.8 \mu \mathrm{g} / \mathrm{ml}$ ) and made to react in dark for 30 mins time at room temperature. Absorbance of the blank, test and control were recorded at $517 \mathrm{~nm}$. The experiment was performed in triplicate and scavenging activity was calculated by using the following formula and expressed as percentage of inhibition. 
BAJOPAS Volume 14 Number 1, June, 2021

$\%$ Inhibition $=$ Absorbance of controlAbsorbance of test $\times 100 \%$

Absorbance of control

The concentration corresponding to the $50 \%$ inhibition $\left(\mathrm{IC}_{50}\right)$ was determined using probit analysis by means of SPSS 16.0 software. The $\mathrm{IC}_{50}$ values obtained are compared with that of ascorbic acid as a standard antioxidant.

Acute toxicity studies of methanolic extract of Vitellaria paradoxa Stem bark and Root

\section{Lethal Dose $\left(\mathbf{L D}_{\mathbf{5 0}}\right)$ Determination}

The method of Lorke (1983) was employed for this test. Thus, the phase I involved the oral administration of three different doses of 10 , 100 and $1,000 \mathrm{mg} / \mathrm{kg}$ of the crude extract, to three different groups of three adult wister albino rats. In the fourth group, three adult male wister albino rats were administered with equivalent/volume of distilled water to serve as control. All the animals were orally administered the extract using a curved needle to which acatheter had been fixed. The animals were monitored closely every 30 minutes for the first 3 hours after administration of the crude extract and hourly for the next 6hours for any adverse effects. Then the animals were left for 72 hours for further observation.

When no death occurred, the phase II was employed, only one animal was required in each group. Groups 1-4, animals were orally given $1,500,2,200,3250$ and $5,000 \mathrm{mg} / \mathrm{kg}$ dose levels of the crude extract. All the animals were left for observation as in stage one.

\section{RESULTS}

Chemo-microscopical studies on the powdered stem bark and root of Vitellaria paradoxa were found to have cellulose cell wall, lignin, calcium oxalate crystals, tannins, starch and mucilage while calcium carbonate was absent in the powdered stem bark but present in the root.

Table 1. Chemo-microscopic Studies of Powdered Stembark and Root of Vitellaria paradoxa

\begin{tabular}{lcc}
\hline Constituents & & Inference \\
\cline { 2 - 3 } & Stem bark & Root \\
Starch & + & + \\
Gum and Mucilage & + & + \\
Cellulose cell walls & + & + \\
Lignin & + & + \\
Aleurone grain & + & + \\
Calcium oxalate crystals & + & + \\
Calcium carbonate & - & + \\
Suberized/Cuticular cell wall & + & + \\
Inulin & + & + \\
\hline
\end{tabular}

Key: + Present, - Absent

The result of average moisture contents using loss on drying method was calculated to be $7.30 \%$ and $6.80 \%$ in stem bark and root respectively. The percentage yield of total ash, acid insoluble and water soluble matter were recorded in percentage values as $7.20 \%, 3.21 \%$ and $6.10 \%$ respectively in powdered stem bark while $8.70 \%, 3.90 \%$ and $6.20 \%$ in the powdered root. The water and ethanol/alcohol extractives obtained were $24.0 \%$ and $20.0 \%$ for stem while $25.50 \%$ and $19.0 \%$ for the root respectively.

Table 2. Physicochemical Constituents of Powdered Stembark and Root of Vitellaria paradoxa

\begin{tabular}{lccc}
\hline Parameters & \multicolumn{2}{c}{ Values $(\% w / w) \pm$ SEM* } & \multirow{2}{*}{ B.H.P Standard } \\
\cline { 2 - 3 } & \multicolumn{2}{c}{ Stem bark } & Root \\
Moisture content & $7.30 \pm 0.33$ & $6.80 \pm 0.33$ & $12-14 \%$ \\
Ash content & $8.40 \pm 0.58$ & $8.70 \pm 0.58$ & $6-19 \%$ \\
Acid insoluble ash & $3.21 \pm 0.33$ & $3.90 \pm 0.33$ & $>1$ \\
Water soluble ash & $6.10 \pm 0.42$ & $6.20 \pm 0.42$ & - \\
Water extractive value & $24.00 \pm 0.33$ & $25.0 .00 \pm 0.33$ & - \\
Ethanol extractive & $20.00 \pm 0.58$ & $19.0 \pm 0.58$ & - \\
value & & & \\
\hline
\end{tabular}

The percentage yield of different extracts (Table 3) showed aqueous had the highest yield $(12.4 \%$ and $14.4 \%$ ) in both stem bark and root respectively. 
BAJOPAS Volume 14 Number 1, June, 2021

Table 3:. Physical Properties of Vitellaria paradoxa Stem bark and Root extracts

Properties

Weight of plant material $(\mathrm{g})$

Weight of extract $(\mathrm{g})$

Percentage yield (\%)

Colour of extract

\begin{tabular}{cccc}
\multicolumn{2}{c}{ Aqueous } & \multicolumn{2}{c}{ Methanol } \\
\hline Stem bark & Root & Stem bark & Root \\
50 & 50 & 50 & 50 \\
6.2 & 7.2 & 5.2 & 5.9 \\
12.4 & 14.4 & 10.4 & 11.8 \\
Brownish & Brownish & Dark Brown & Dark Brown \\
Gummy & Gummy & Gummy & Gummy
\end{tabular}

Texture of extract

Alkaloid, flavonoids, saponins, tannins, steroids, triterpenes, carbohydrate and phenols were extracts. Cardiac glycoside was detected in both aqueous and methanolic root extract but absent detected in both aqueous and methanol extracts while anthraquinones was absent in all the in the stem bark extract.

Table 4: Qualitative Phytochemical screening of Vitellaria paradoxa Stem bark and Root extracts

\begin{tabular}{l} 
Constituents \\
Alkaloid \\
Flavonoid \\
Saponins \\
Cardiac glycoside \\
Tannins \\
Steroid \\
Triterpenes \\
Phenol \\
Anthraquinones \\
Carbohydrate \\
\hline
\end{tabular}

$\begin{array}{cc} & \text { Aqueous } \\ \text { Stem bark } & \\ + & \\ + & \\ + & \\ - & \\ + & \\ + & \\ + & \\ + & \\ - & \\ + & \end{array}$

$\begin{array}{ll}\text { Root } & \text { Stem } \\ + & \\ + & \\ + & \\ + & \\ + & \\ + & \\ + & \\ + & \\ - & \\ + & \end{array}$

The antioxidant activity of the methanol stem bark and root extracts of Vitellaria paradoxa and ascorbic acid used as control were used found to extracts, the lower the absorbance and consequently the higher the percentage inhibition of the free radicals.

Methanolic

be dose dependent. The higher the dose of the

Table 5. Antioxidant activities of Methanolic Stem bark and Root extract of Vitellaria paradoxa

\begin{tabular}{lcclcccc}
\hline Analyte & \multicolumn{7}{c}{ Concentration $(\mu \mathrm{g} / \mathrm{ml}) / \%$ Inhibition } \\
\cline { 2 - 8 } & $\mathbf{1 0 0 0}$ & $\mathbf{5 0 0}$ & $\mathbf{2 5 0}$ & $\mathbf{1 2 5}$ & $\mathbf{6 2 . 5}$ & $\mathbf{3 1 . 2 5}$ & $\mathbf{1 5 . 6}$ \\
Ascorbic acid & 99.7 & 99.3 & 98.7 & 97.4 & 95.4 & 92.2 & 87.5 \\
$\begin{array}{l}\text { Root extract } \\
\text { Stem bark }\end{array}$ & 76.8 & 73.1 & 68.7 & 61.2 & 60.3 & 55.8 & 55.2 \\
extract & 98.9 & 94.2 & 92.6 & 90.7 & 78.7 & 76.5 & 75.6 \\
\hline
\end{tabular}

The trend of the inhibition of DPPH radical by the extract was concentration dependent with respect to the $\mathrm{IC}_{50}$ values (concentration of the methanolic extract to cause $50 \%$ inhibition), the
DPPH radical scavenging ability of the methanolic extract showed the following trend Ascorbic acid > Stem bark extract> Root extract.

Table 6. IC 50 values of DPPH Scavenging Effects of Ascorbic acid, Methanolic Stem and Root extract of Vitellaria paradoxa

\begin{tabular}{lc}
\hline Analytes & $\mathrm{IC}_{50}$ value $(\mu \mathrm{g} / \mathrm{ml})$ \\
\hline Ascorbic acid & 0.79 \\
Methanolic Root extract & 5.604 \\
Methanolic Stem bark extract & 2.713 \\
\hline
\end{tabular}

No death was recorded in the first phase of the study in rats. In the second phase, doses of $1500 \mathrm{mg} / \mathrm{kg}, \quad 2250 \mathrm{mg} / \mathrm{kg}, \quad 3250 \mathrm{mg} / \mathrm{kg}$ and $5000 \mathrm{mg} / \mathrm{kg}$ were used and no death was also recorded. The oral median lethal dose $\left(L D_{50}\right)$ for the methanol stem bark and root extract of Vitellaria paradoxa was therefore estimated to be greater than $5000 \mathrm{mg} / \mathrm{kg}$ and no sign of behavioural changes were also observed. 
Table 7. Acute Toxicity Study of Methanol extracts of Vitellaria paradoxa Stem bark and Root

\begin{tabular}{ccccc}
\hline $\begin{array}{c}\text { Methanolic } \\
\text { extract }\end{array}$ & Group & $\begin{array}{c}\text { Number of } \\
\text { Animals }\end{array}$ & Dose $(\mathrm{mg} / \mathrm{kg})$ & $\begin{array}{c}\text { Mortality recorded after } \\
24 \mathrm{hrs}\end{array}$ \\
\hline Phase I & I & 3 & 10 & $0 / 3$ \\
& II & 3 & 100 & $0 / 3$ \\
Phase II & III & 3 & 1000 & $0 / 3$ \\
& I & 1 & 1500 & $0 / 1$ \\
& II & 1 & 2250 & $0 / 1$ \\
& III & 1 & 3250 & $0 / 1$ \\
& IV & 1 & 5000 & $0 / 1$ \\
\hline
\end{tabular}

\section{DISCUSSION}

Chemo-microscopical features of powdered stem bark and root of Vitellaria paradoxa revealed the presence of cellulose cell wall, lignified cell wall, mucilage, tannins, starch, suberin and calcium oxalate crystals while calcium carbonates were found to be absent. The microscopic structures are most valuable in the identification of powdered drug as their identification is largely based on the form, the presence or absence of certain cell types and cell inclusions (Jeremiah et al., 2019). The physicochemical parameters including the moisture content, acid insoluble ash, water soluble ash, alcohol extractives value, water extractives and total ash values were determined from the powdered parts of the plant (Jeremiah et al., 2019). These are values that are very important as basis to judge the identity, purity and in detecting adulterants in a crude drug (Jeremiah et al., 2019).Moisture content $(5.53 \%)$ was not high which indicated less chances of microbial degradation of the drug during storage. The general requirement of moisture content in crude drug is recommended not to be more than $14 \%$ British Herbal Pharmacopoeia B.H.P (1990). The value obtained in this research work was within the accepted range. Determination of the moisture content helps preventing degradation of drug during storage. The lower the value, the less likelihood of degradation of drug and suggests better stability of the product. Moisture is considered an adulterant because of its added weight as well as the fact that excess of moisture promotes mold and bacterial growth (Jeremiah et al., 2019). Total ash value represents both the physiological and nonphysiological ash from the plant. The nonphysiological ash is an indication of inorganic residues after the plant drug is incinerated. The acid insoluble ash values (3.21\% and $3.9 \%)$ obtained in this study indicated that the plant was in good physiological condition and contained little extraneous matter such as sand, silica and soil. The total ash value is used as criteria to judge the identity and purity of drugs (Jeremiah et al., 2019).
Extractive value is determined when a given amount of plant material is extracted with a particular solvent. When the crude drug is extracted with a particular solvent, it produces a solution that contains several constituents (Jeremiah et al., 2019). The nature of the crude drug and the solvent used determines the constitution of the phyto-constituents present (Jeremiah et al., 2019). It also helps to determine if the crude drug is debilitated or not (Jeremiah et al., 2019). This study indicated that ethanol gave lower extractive value $(20.0 \%$ and $19.0 \% \mathrm{w} / \mathrm{w}$ ) compared to water which had extractive value of $24.0 \%$ and $25.5 \% \mathrm{w} / \mathrm{w}$ in stem bark and root respectively.

The antioxidant activity of the plant (stem and root) determined (Table 7) were expressed in terms of $\mathrm{IC}_{50}$ value. Vitellaria paradoxa was found to possess lower DPPH scavenging activity compared to the standard drug. However, the scavenging ability of the stem bark extracts are higher than that of the root extracts. Moreover, smaller $\mathrm{IC}_{50}$ values means better scavenging activity/antioxidant potential and higher $\mathrm{IC}_{50}$ value, indicate lower activity (Cesur et al., 2017). This indicate that the Vitellaria paradoxa extracts have an appreciable antioxidant activity and might be useful as therapeutic agents. The remarkable antioxidant activities exhibited by stem bark and root methanol extracts have made them potential free radicals scavenging agents, and this is probably due to their phenolic, alkaloids, flavonoids, terpenoids and vitamins constituents (Sri-sudewi et al., 2014). These might be associated with the folkloric use of the plant in traditional medicine in Nigeria for the treatment of numerous diseases and health conditions such as malaria, fever, pains, diabetes and convulsion (Akuodor et al., 2015).The best antioxidant activities exhibited by stem bark methanol extract is probably due to the presence of hydroxyl group attached to the aromatic ring of their molecules. This is supported by the report of Akinmoladun et al., (2007) and Ahmad, (2011) where they stated that the mechanism of reduction of DPPH molecule by plant extracts or isolated pure 
BAJOPAS Volume 14 Number 1, June, 2021

compounds or fractions is due to the presence of hydroxyl groups on their molecules. This mechanism is possible in plants that are rich in flavonoids, tannins, anthocyanins, and anthocyanidins because they met the structural requirements.

Acute toxicity studies of Vitellaria paradoxastem bark and root were performed using the Lorke (1983) methods and using the limit dose test of Up and Down method. With careful observations of experimental animals from the first 30 minutes up to the 14th day, it was revealed that there were no deaths and any sign of toxicity such as loss or increase in weight, tiredness, abdominal constrict convulsion, hyperactive, weakness, diarrhea or increased diuresis within the short and long term effect in rats dosed with $5000 \mathrm{mg} / \mathrm{kg}$ body weight of the Vitellaria paradoxa extracts (stem and root methanol extracts). The outcome of the study of Alhassan et al.(2014) gave an $L_{50}$ of $2000 \mathrm{mg} / \mathrm{kg}$ and this guided our choice of dose used (5000 $\mathrm{mg} / \mathrm{kg}$ ). The $L D_{50}$ was found to be greater than $5000 \mathrm{mg} / \mathrm{kg}$ body weight orally, and this suggested that the extract has low acute toxicity when administered orally. This may be attributed to the incomplete absorption brought about by inherent factors limiting absorption in the gastro intestinal tract (Dennis, 1984). The present study agrees with the work done by Prasanth et al., (2015); Ugbogu et al., (2016); Kofi et al., (2014) and Adesegun et al., (2016); . Bruce, (2006) reported that any substance with $\mathrm{LD}_{50}$ estimated to be greater than 2000-5000 $\mathrm{mg} / \mathrm{kg}$ body weight given orally could be considered to be of low toxicity and safe. Similarly, the chemical labelling and classification of acute systemic toxicity based on oral $\mathrm{LD}_{50}$

\section{REFERENCES}

Adesegun, S. A., Celestina, I. O. and Coker, H. A. (2016). Analgesic and Antioxidant Activities of Stem Bark Extract and Fractions of Petersianthus macrocarpus. Pharmacognosy Res. 8(3): 181-185.

Ahmed, A. (2011). Pharmacognostic Studies and Isolation of Antioxidant Principles from Tacazzea apiculate Olive (Periplocaceae. P.hD Dissertation Submitted to Department of Pharmacognosy, Ahmdu Bello University, Zaria - Nigeria, 109.

Akinmoladun, A. C., Ibukun, E. O., Afor, E. , Obuotor, E. M. and Farombi, E.O. (2007). Phytochemical Constituent and antioxidant activity of extract from the leaves of Ocimum gratissimum. Scientific Research and Essay 2 (5), 163-166.

Akuodor, G.C., Essien, A.D., Essiet, G.A., DavidOku, E., Akpan, J.L., and Udoh, F.V. values recommended by the Organization of Economic Cooperation and Development (OECD, Paris, France) and (Walum, 1998) are as follows: less than $5 \mathrm{mg} / \mathrm{kg}$ : very toxic, greater than 5 but less than $50 \mathrm{mg} / \mathrm{kg}$ : toxic, greater than 50 but less than $500 \mathrm{mg} / \mathrm{kg}$ : harmful, and, greater than 500 but less than $2000 \mathrm{mg} / \mathrm{kg}$ : no label. The very high $L_{50}$ observed is not a conclusive finding about the safety of the extracts of Vitellaria paradoxa, higher doses could be tested for better understanding of its effects if use for a long period of time and for proper recommendation on its future utilization (Ogbonnia et al., 2011).

\section{CONCLUSION}

The established pharmacognostic standards for the powder of Vitellaria paradoxa stem bark and root could be used as a diagnostic tool for the standardization and identification of this medicinal plant for its purity and quality in the future and hence, inclusion into the pharmacopoeia for official use. The extracts have some secondary metabolites namely alkaloids, tannins, steroids, triterpenes, flavonoids, cardiac glycosides and saponins. The Acute toxicity $\left(\mathrm{LD}_{50}\right)$ of the stem bark and root extracts of Vitellaria paradoxa(Methanol) was found to be greater than $5000 \mathrm{mg} / \mathrm{kg}$ and is considered safe for use. The extracts have free radicals scavenging effects that are dose dependent. This supports the basis for the use of this plant traditionally for different ailments. The effects are probably due to phenolic compounds, flavonoids, tannins and some elements in the plant.

(2013). Evaluation of antipyretic potential of Pseudocedrela kotschyi Schweint. Hams (Meliaceae). European Journal of Medicinal Plants, 3(1), 105113.

Alhassan, M. A., Ibrahim, M., and Musa, I. A. (2014). Phytochemical Screening and Antimicrobial Evaluation of Stem Bark Extract of Pseudocedrela kotschyi (Herms). British Journal of Pharmaceutical Research, 4(16): 19371944.

British Herbal Pharmacopoeia (1990). British Herbal Medicine Association. Bournemouth: Dorset. 1st edition. Vol.1. Pp. 1-2.

Cesur, C. B., Coşge, S., Cennet, Y., Tansu, U., Murat, K. (2017).Antioxidant activity of fruit extracts of Prangos ferulacea (L.) 
BAJOPAS Volume 14 Number 1, June, 2021 Lindl.J. Inst. Sci. \& Tech., 7(4): 249256.

Evans, W.C. (2009). Trease and Evans Pharmacognosy. 16th edition. Elselviers Ltd., UK, Pp.560-562, 568-570.

Gomathi, D., Ravikumar, G., Kalaiselvi, M., Devaki, K. and Uma, C. (2013). Efficacy of Evolvulus alsinoides (L.) on insulin and antioxidants activity in pancreas of Streptozotocin induced diabetic rats. Journal of Diabetes and Metabolic Disorders, 12 (1), 1.

Jeremiah, C., Katsayal, U.A., Nuhu, A., Nuhu, H.D.(2019). Pharmacognostic and Elemental Analysis of the Leaves of Tapinanthus globiferus (A. Rich). Tiegh. Res J Pharmacogn; 6(1): 11 -18.

Joseph, L., Evans, D., Betty, A., Maddux, G. and Grodsky, M. (2002). Oxidative Stress and Stress-Activated Signaling Pathways: A Unifying Hypothesis of Type 2 Diabetes.

Kofi, D., Laud, N.K.O., Wonder, K. M. A. and Eric, W. (2014). Acute and Sub-Chronic Toxicity Studies of Aqueous Extract of Root Bark of Cassia Sieberiana D.C. in Rodents. Journal of Applied Pharmaceutical Science, 4 (4), 84-89.

Krishnasamy, R. (2013). Antioxidant and antidiabetic activity of Tectona grandis (L.) In Alloxan induced albino rats. Asian Journal of Pharmaceutical and Clinical Research, 6(3), 174-177.

Kunle, O.F., Egharevba, H.O., and Ahmadu, P. O. (2012). Standardization of herbal medicines - A review. International Journal of Biodiversity and Conservation, 4(3), 101-112.

Lovett, P., Hag, N (2000). Evidence for a tropic selection of the Shea nut tree (Vitellaria paradoxa). Agro-forestry Systems. 48:293-304.

Mohan, Y., Jesuthankaraj, N. and Ramasamy, N. (2013). Antidiabetic and antioxidant properties of Triticum aestivum in streptozotocin-induced diabetic rats. Journal of Advances in Pharmacological Sciences, 2013.

Ogbonnia, S.O., Mbaka, G.O., Anyika, E.N., Emordi, J.E. and Nwakakwa, N. (2011). An evaluation of acute and subchronic toxicities of a Nigerian polyherbal tea remedy. Pakistan Journal of Nutrition, 10:1022-8. pp. 115-127.

Prasanth, K.M., Suba, V., Ramireddy, B. and Srinivasa, B.P. (2015). Acute and Subchronic Oral Toxicity Assessment of the Ethanolic Extract of the root of Oncoba spinosan (Flacourtiaceae) in Rodents. Tropical Journal of Pharmaceutical Research, 14(10), 18491855.

Rahman, T., Hosen, I., Islam, T. and Shekhar, U. (2012). Oxidative stress and human health. Advances in Bioscience and Biotechnology, 3(7A), 997.

Sani, U. and Dailami, S. A. (2015). Synthesis, characterization, antimicrobial and antioxidant studies of metal(II) complexes of schiff base derived from 2hydroxy-1-naphthaldehyde and hydrazine monohydrate, Chemsearch Journal, 6(2): 35-41.

Sri-sudewi, Subagus, W. and Puji, A. (2014). Isolation and identification of free radicals scavenger from daucus carota I leaves Trad. Med. J., vol. 19(3),142-148.

Ugbogu, E A., Emmanuel, O., Iheanyichukwu E, Friday U., Emmanuel A., Chinyere G. C, Faith, E. and Chizoba J. U (2016). Toxicological assessment of the aqueous dried leaf extracts of Senna alata L. in wistar rats. African Journal of Pharmacy and Pharmacology Vol. 10(34), pp. 709.

Walum, E. (1998). Acute oral toxicity. Environmental Health Perspective, 106, 497-503.

WHO (1992). Quality Control Methods for Medicinal Plant Materials. World Health Organization, Geneva.

WHO (1996a). Quality Assurance of Pharmaceuticals: A Compendium of Guidelines and Related Materials, Good Manufacturing Practices and Inspection. World Health Organization, Geneva. 2.

WHO (1996b). Guidelines for the Assessment of Herbal Medicines. WHO Technical Report Series, World Health Organization, Geneva. 863.

World Health Organization (2011). Quality Control Methods for Medicinal Plants. WHO, Geneva, Switzerland, Pp. 31. 